Баттахов П.П.

Кандидат юридических наук, старший научный сотрудник сектора предпринимательского и корпоративного права ФГБУН Институт государства и права РАН

\title{
ОСНОВНЫЕ ПРОБЛЕМЫ ПРАВОВОГО РЕГУЛИРОВАНИЯ ОХРАНЫ И ЗАЩИТЫ ОКРУЖАЮЩЕЙ СРЕДЫ В АРКТИЧЕСКОЙ ЗОНЕ РОССИЙСКОЙ ФЕДЕРАЦИИ В УСЛОВИЯХ ДОБЫЧИ ПОЛЕЗНЫХ ИСКОПАЕМЫХ
}

\begin{abstract}
Аннотация
В статье рассматривается понятие арктических зон России. Рассмотрены основные проблемные вопросы экологической охраны и защиты арктических территорий $в$ соответствии с законодательством РФ и международными конвенциями. Рекомендованы добываюшим компаниям в дальнейшем предупредительные работы и усиленные меры устранения экологических и экономических катастроф. Исследовань мерь ответственности при предпринимательской деятельности в арктической зоне. Необходимо внести ряд изменений в законодательстве страны. Bо-первых, $в$ правоотношении между государством и добывающими компаниями по хозяйственной деятельности. Во-вторых, ужесточить санкции по экологическим направлениям со стороны промышленных компаний. Предлагается в лучшем случае принять отдельный кодификационный акт.
\end{abstract}

Ключевые слова: Арктическая территория, фауна, добывающая компания, полезные ископаемые, санкция, новые технологии, федеральный уровень.

Keywords: Arctic territory, fauna, mining company, minerals, sanction, new technologies, federal level.

Арктическая зона России - уникальная территория нашей необъятной страны, ведь мы не делимся на разные национальности и территории. У нас одна страна, которая неотчуждаема и целостна как один кулак. Наши родители не делили на хороших и плохих своих детей. Поэтому все федеральные законы на всей территории страны регулируют правоотношения одинаково. Все субъекты России по экономическим отношениям и по уровню продолжительности жизнедеятельности народов, живущих на территории страны, должны развиваться равнозначно по всей территории Российской Федерации. Например, в живой природе без холодного воздуха не было бы другого воздуха, без арктических территорий не было бы других территориальных зон.

Многие Арктические государства заинтересованы в развитии северного морского пути. Поэтому у России имеется большое преимущество перед партнерами, при развитии Арктики наша страна должна быть Координатором международного соглашения. В арктических зонах России нужны государственные инвестиции, то есть внутренняя финансовая помощь. В настоящее время вкладывание для развития происходит несмотря на санкции от зарубежных партнеров, прорывом больших финансовых проектов будет именно Арктика. Со временем арктические государства, современные страны с передовой экономикой и международные корпорации обязаны инвестировать проекты для развития мировой цивилизации. Многополярный мир станет драйвером оттепели инвестиционного климата Российской Федерации. Нам нельзя закрываться от внешней инвестиции. Но, с другой стороны, мы не обязаны уступить доминирующее положение передовым странам по Арктике. Российская Федерация всегда должна быть передовой по всем отношениям в арктической зоне.

В России арктическая зона состоит из различных субъектов страны, в количестве всего девять. Это, например:

1. Архангельская область: города Архангельск, Новодвинск, Северодвинск; Мезенский, Приморский, Онежский, Лешуконский, Пинежский районы, городской округ «Новая Земля». 
2. Республика Саха (Якутия): Абыйский, Аллаиховский, Анабарский, Булунский, Верхнеолымский, Верхоянский, Жиганский, Момский, Нижнеколымский, Оленекский, Среднеколымский, Усть-Янский, Эвено-Бытантайский районы.

3. Красноярский край: Норильск, Таймырский Долгано-Ненецкий и Туруханский районы, сельские поселения Эвенкийского муниципального района: «Поселок Суринда», «Поселок Тура», «Поселок Нидым», «Поселок Учами», «Поселок Тутончаны», «Поселок Ессей», «Поселок Чиринда», «Поселок Эконда», «Поселок Кислокан», «Поселок Юкта», 4. Республика Карелия: Беломорский, Калевальский, Кемский, Костомукшский, Лоухский, Сегежский районы.

4. Республика Коми: городские округа Воркута, Инта, Усинск; Усть-Цилемский район.

5. Чукотский автономный округ.

6. Ямало-ненецкий автономный округ.

7. Мурманская область.

8. Ненецкий автономный округ, На этой уникальной территории проживают разные коренные малочисленные народы Севера[1].

Многие исследователи предполагают, что самый эффективный путь развития арктических зон в России - это добыча полезных ископаемых, например, углеводорода. По последним данным геологов запас имеется примерно на 50 лет добычи. Следующим критерием развития является внедрение новых технологий на территории Арктики, со временем при больших холодах снаружи должны работать современные роботы. В наше время многие работники получают неизлечимые хронические болезни после Севера. Результат получаем каждый год. Это потеря трудоспособности и колоссальные расходы для восстановления здоровья работников. Важно развитие на местах медицинских учреждений и санаториев для восстановления здоровья рабочего класса. Далее - сохранения уклада жизни и этноса малочисленных народов Севера. Стратегическим моментом охраны и защиты территорий арктических зон является укрепление военных баз на местах, еще одним основным направлением является поддержка эко предпринимателей, которые занимаются очисткой биосферы.

Благодаря экологам мира сохраняется живая фауна от загрязнения добывающих государств. По сегодняшнему состоянию образующие бюджет компании России по добыче полезных ископаемых загрязняют природу страны. Здесь системный подход по санкциям этим компаниям должна быть жестким. В отчетах прозрачность прибылей и расходов компаний не видим. Если будет продолжаться скрытное производство технологий добычи полезных ископаемых, современный мир разрушится на глазах.

Арктический ландшафт богат ископаемыми минералами, в арктических территориях России имеются вся таблица Менделеева. По соотношению с другими арктическими странами мы больше добываем на местах вечной мерзлоты. Правовое регулирование охраны экологической деятельности происходит самостоятельными нормативно-правовыми актами. В арктических зонах в России необходимо принимать отдельный кодификационный акт, который регулировал бы более широкие правоотношения.

По действующему законодательству граждане Российской Федерации[2] не могут контролировать добывающие компании, отчетность доходов и расходов промышленных компаний должна быть прозрачной для всех. Только тогда мы можем реализовывать поставленные задачи перед народом по развитию экономики и экологии страны. Основная локация промышленных компаний должно быть на местах работы, то есть добывающие организации обязаны зарегистрироваться в арктической зоне.

Россия - член мирового арктического сообщества, и как добывающая страна обязана соблюдать все международные нормативно-правовые акты и в соответствии этих актов принять внутренние нормативно-правовые акты. В данное время недостаточно регулируются все правоотношения на должном уровне. Следовательно, необходимо принимать специальный кодификационный нормативный акт. Законодательная база должна обновляться по Арктике. 
Большая экологическая катастрофа в близлежащем будущем неизбежна, если мы не будем соблюдать все необходимые нормы по мировым стандартам. В стране для этого приняты соответствующие нормативно-правовые акты согласно международным стандартам. Ученые России поднимают ежегодно в научных конференциях вопрос: «почему в арктических государствах мира не добывают природные ископаемые? Если все же добывают, то не в таком количественном соотношении». Второй вопрос на повестке дня тоже часто повторяется: «зачем в России добывают так много полезных ископаемых»? Нас настораживает, когда с каждым годом климат в Арктике меняется, и, соответственно, такие вопросы поднимают ученые и независимые экологи.

На федеральном уровне необходимо провести предупредительные работы по экологическим вопросам, только тогда можем избежать экологических глобальных катастроф. Усилием Президента России проводятся разные мероприятия сохранения арктических территорий. Согласно Указу Президента РФ от 26 октября 2020 г. N 645 «О Стратегии развития Арктической зоны Российской Федерации и обеспечения национальной безопасности на период до 2035 года»[3] государственные органы всех уровней власти обеспечивают улучшение жизни населения. Кроме этого, они обеспечивают совершенствование действующего законодательства современным экономическим и политическим реалиям комплексного устойчивого развития хозяйственного освоения арктических зон. Указ регулирует широкий спектр стратегических направлений арктических зон России на десять лет, и данный нормативный акт дает оптимальное развитие и сохранение Арктики.

Многие ученые пишут о том, что в Арктике самым основным вопросом является демографическая проблема. Убыль населения происходит не только в арктической зоне. Данная проблема на повестке дня стоит давно, в целом в стране последние годы рождаемость падает, а смертность увеличивается. Если сравнивать с Китаем и Индией у них наоборот проблемный вопрос -это перенаселение. В арктической зоне не нужно переселять людей. Вмешательство людей приводит к большому экологическому урону, уничтожаются животные. Последние пять лет льды в летнее время стали таять и исчезать. Пришлые люди стали больше загрязнять морские воды разными химическими элементами. Промышленность выбрасывает много отходов на открытое пространство. Ни в коем случае не стоит развивать сельское хозяйство как в Краснодаре. Вечная мерзлота растает, тогда наступит конец человечества. С этим шутить нельзя.

В последнее время на федеральном уровне ученые ставят разные экологические вопросы, например, загрязнение российской Арктики промышленными компаниями на местах добычи полезных ископаемых. Данные вопросы обсуждаются и предупреждают российское общество в разных научных всероссийских конференциях и международных форумах. Иногда по возможности поднимаются вопросы на совещаниях исполнительной и законодательной власти России. К сожалению, происходили крупные экологические аварии двадцать первого века на территории Республики Саха (Якутия) по вине алмазодобывающей компании «Алроса». В 2017 году трагедия произошла в городе Мирный, в шахту прорвалась вода и погибли работники рудника «Мир». Через два года добывающая компания с мировым именем второй раз показала несостоятельность работы по экологическим стандартам в результате прорыва воды, и донные отложения из технологических котлованов алмазодобывающей компании попали в реки Ирелях, Малая Ботуобия и Вилюй[4]. Катастрофа оказалась значительной для жизни важных рек Республики и жителей группы Вилюйских улусов. Последние годы жители чаще стали болеть разными онкологическими болезнями, до сих пор не ведутся очистительные работы, не должным образом возмещены расходы.

В прошлом году в Красноярском крае произошла по масштабу разрушения живой фауны и по освещенности именно в государственных средствах информации экологическая катастрофа по вине добывающей компании «Норникель». В реку Амбарная вылилось дизельное топливо порядка двадцати тысяч тонн, виновная сторона до сих не может 
полностью устранить аварию. Благодаря независимым экологам мира и России узнали масштабность аварии. Почему в современное время в арктических зонах происходят мировые экологические катастрофы? Здесь имеется несколько ответов. Очевидно, это безнаказанность и коррумпированность местных властей по горизонтали. Компании в целях получения огромной прибыли, экономической выгоды не соблюдают технику безопасности на производстве. Износ основных средств не восстанавливают на должном уровне. К сожалению, еще одному фактору при добыче полезных ископаемых не уделяют большое внимание при защите экосистемы. Российская Федерация широка по территориальной части, поэтому не уделяет особого контроля со стороны вышестоящих надзирающих органов государственной власти. В другой части России на экологические катастрофы на должном уровне активные граждане и государственные служащие не обращают особого внимания. На самом деле, данная проблема общая для всей страны и даже всего человечество на планете Земля.

Необходимо сделать выводы на уровне страны, ведь вся территория России включает в себя территории ее субъектов, внутренние воды и территориальное море, воздушное пространство над ними[5]. То есть у нас страна одна, и территориальная целостность и верховенство закона являются основными признаками России. Это взаимная ответственность государства и общества. Виновные добывающие компании и должностные компании обязаны отвечать в соответствии по максимальной санкции таких кодификационных нормативно-правовых актов страны. Например, по Уголовному кодексу Российской Федерации, Кодексу об административных правонарушениях Российской Федерации, Трудовому кодексу Российской Федерации, Гражданскому кодексу Российской Федерации и т. д. Необходимо усовершенствовать имеющиеся нормативно-правовые акты и ужесточить санкции по отношению к юридическим лицам, индивидуальным предпринимателям и физическим лицам. В ближайшие годы в стране будет сохраняться экологическая среда и экономическое благополучие исконных народов Арктики. В России имеется большой задел роста экономики по всем направлениям и потенциала жизнедеятельности гражданина страны. Необходимо внедрить в арктических субъектах государственную внутреннюю политику страны, когда местонахождение добывающей компании позволит трудоустроить местных коренных жителей. Данный жизненно важный вопрос решит несколько не решенных задач перед государством, которые пока не реализуются страной. Значит, если решится данный вопрос, то, во-первых, цикл урбанизации затормозится. Во-вторых, местные кадры не будут нарушать законодательство страны как пришлые или наемные работники.

Необходимо принять меры ответственности добывающих компаний перед государством. Согласно законодательных актов они обязаны возместить понесенные расходы, в течение нескольких лет провести мониторинговые работы по экологии, медицинское сопровождение и помощь пострадавшим жителям от экологической катастрофы. Чтобы другим не повадно было, государство обязано усложнить санкции добывающим компаниям и по отношению к экологическим нарушениям. Иначе не сможем остановить экологические катастрофы на территории Арктики. В дальнейшем будет вырабатываться коллективный иммунитет.

Отдельный вопрос по коренным малочисленным народам, которые проживают в Арктической зоне. Всего согласно переписи населения по численности они составляют примерно 50000 тысяч человек. По национальным критериям: чуванцы, нивхи, алеуты, кереки, ительмены, коряки, юкагиры, кеты, эскимосы, тофалары тубалары, кумандинцы, теленгиты, долганы, чулымцы, челканцы, телеуты, сойоты, тувинцы-тоджинцы, шорцы, тазы, камчадалы, ороки, негидальцы, ульчи, эвены, орочи, удэгейцы, нанайцы, эвенки, энцы, селькупы, ненцы, нганасаны, саамы, ханты, вепсы, манси[6]. Исконные народы как старые люди очень мужественные по отношению жизни и быту. В наше время мир меняется и, соответственно, люди меняются. Но исконные народы сохранили вероисповедания, язык и уклад жизни, у них много всяких традиций. Без таких отважных народов не сохранили бы такую Арктику, которую мы видим в настоящий момент. Исконные народы с климатом 
охраняют и защищают натуральную природу. Последние годы исконные народы Севера встречают много проблем, связанных с территорией. При освоении территорий при добыче полезных ископаемых добывающие компании нарушают права народов, без всяких оснований забирают земельные участки сельскохозяйственного назначения, взамен часто ничего не предлагают. Ведь в правовом государстве права человека должны быть превыше всего. Следующий больной вопрос - это разграничение охоты и рыболовства на местах. В нормативных актах Российской Федерации ежегодно ужесточаются санкции по рыболовству и охоте. Ведь исконные народы Севера, как и вся арктическая зона, без этих промысловых занятий постепенно будет отмирать. Если государство хочет изменить уклад жизни исконных народов на местах в цивилизованную сторону, тогда государство должно предоставить качественное образование. По всей России стоит большая проблема по трудоустройству местных жителей на местах проживания. Такой сложный вопрос на федеральном уровне решать не могут, молодежь уезжает в центральные города, урбанистический процесс мы не можем искусственно остановить. Такая проблема стоит в арктической зоне России, поэтому с помощью государства в промышленных компаниях необходимо трудоустроить местных коренных жителей Арктики. Точечная помощь начинающим предпринимателям, социальным предприятиям, им необходимо выдавать субсидии для строительства жилых домов. Дотировать из федерального бюджета в казну местного самоуправления для строительства кампуса школьников и пансионатов разного типа. Если в арктических зонах поднимется уровень социального блока, только в этом случае уменьшится отток населения. Хозяйствующие промышленные компании обязаны поддержать социальное направление, государство обязано закрепить в законодательстве данное правило поведения. Имеются еще проблемное направление в Арктике - это слабая медицина и некачественное питание. Последние годы в арктических регионах люди стали болеть разными онкологическими болезнями. Чтобы лечиться и сделать операцию, нужно ехать в центральную часть России или зарубежные страны. Многие жители не находят неподъёмные суммы для лечения. Развитие любой болезни происходит из-за несоблюдения правил на первичных осмотрах. В поликлиниках нет врачей по узким направлениям. Причины разные по регионам, но основная проблема - это сокращение медицинских работников, то есть нехватка врачей. Если есть вакантное место, многие выпускники не приезжают работать в арктические регионы. По вопросу питания северный завоз в отдаленных районах стоит в три раза дороже, и по качеству привозят продукты не первой свежести. Дети обязаны питаться качественно, тем более в таких климатических условиях жизни. Следовательно, вышеперечисленные вопросы необходимо решить на федеральном уровне с помощью соответствующих нормативно-правовых актов.

На текущий момент необходимо обособить один ключевой момент работы хозяйствующих субъектов при освоении арктических пространств. Доходы, поступающие от оборота и сбыта природных ресурсов, должны частично оставаться для того, чтобы развивать природный потенциал Арктики[7].

Самый главный фактор сохранения в арктической зоне зеленой фауны, вечной мерзлоты и развития уклада местных жителей - это совместная самозащита всех граждан России против экологических и экономических преступлений. В наше время необходимо разработать Концепцию развития арктических территорий внутри страны и совместную международную программу арктическими государствами, на основании данных важных фундаментальных документов принимать и развивать Арктику мира. Для этого необходимо аккумулировать все умы и денежные средства. Передовые российские научные организации в будущем должны в течение пяти лет организовать комплексную экспедицию на территории Арктики. Государства обязана поддержать ученых в материальном плане для успешных результатов. В целом, системный подход по направлению экологического и экономического развития арктических зон со стороны государственной власти придаст большой толчок развития Российской Арктики. В последующем мы обязаны проводить предупредительные работы в отношении промышленных компаний, чтобы не было 
повторных экологических катастроф на местах добычи полезных ископаемых. По этому вопросу должны заниматься независимые экологи и создавать на уровне федеральной власти контролирующий самостоятельный надзирающий орган по экологическим катастрофам. Нам необходимо меняться независимо от ментальности и территориального деления. У нас Арктика для России - одна. Принятые меры должны работать независимо от должностных лиц и промышленных компаний. Перед законодательством все одинаковы, все должны отвечать за содеянное преступление или гражданский убыток. Только тогда остановим экологическую катастрофу в арктической зоне. Циркумполярное право регулирует все отношения в Арктике. В университетах и институтах страны нужно включить отдельный предмет «Право коренных народов Севера». Необходимость ряда требований меняет наше общества, трендом в арктической зоне должен быть человек.

\section{Литература}

1. «Арктическая зона России» Интернет-ресурс https://clck.ru/VYJTZ

2. Синяжников Д.А., Ребрищев Н. М. Граждане Российской Федерации -субъект

общественного контроля за деятельностью полиции // Вестник экономической безопасности. М.; №1.2016. С.239-242.

3. Баттахов П.П. Особенности правового регулирования современной Арктики // Экономические исследования и разработки. 2020.№11. С.41-48.

4. "В Якутии ищут виновных в загрязнении рек отходами недропользования" https://www.kommersant.ru/doc/3730492

5. Конституция Российской Федерации.

6. "Коренные малочисленные народы Севера, Сибири и Дальнего Востока Российской Федерации" https://clck.ru/TgJrP

7. Баттахов П.П. Особенности правового регулирования отношений в юридической, экономической и социальных сферах в Арктике // Modern Science. 2020. № 6-1. С. 292-297. 